\title{
The Role of Ecological Science in Environmental Policy Making: from a Pacification toward a Facilitation Strategy
}

\author{
$\underline{\text { Lucien Hanssen }}^{1}, \underline{\text { Etiënne Rouwette }}^{2}$, and Marieke M. van Katwijk $^{3}$
}

\begin{abstract}
Based on a Dutch case study on shellfish fishery policy making and a literature review, we expand existing guidelines for coastal zone management. We deduce constraints for handling societally contested and scientifically complex environmental issues. Our additions focus on problem structuring and handling of scientific uncertainties. Both are means to increase consensus about beliefs, ambitions, and directions for solutions. Before policy making can take place, complex environmental issues need to become more structured by reducing either scientific uncertainty or societal dissent: the "pacification strategy" and the "facilitation strategy," respectively. We show that the use of a pacification strategy, in which science is expected to pacify stakeholders, is not an answer, as uncertainties are likely to remain high due to a different pacing of scientific progress and policy-making demands. Instead, we propose a facilitation strategy in which stakeholders formulate shared ambitions and directions for solutions at an early stage, and ecological scientists extend their participation in the process by scientifically assessing policy alternatives. With an eye to giving ecological science a significant role in policy making and management, we present an improved set of guidelines, incorporating the facilitation strategy by focusing on balancing economic and ecological interests and shared policy formulation by scientific inquiry instead of political opportunity.
\end{abstract}

Key Words: coastal zone management; guidelines; problem structuring; scientific assessment, scientific uncertainty; societal dissent; stakeholder engagement

\section{INTRODUCTION}

In the last decade, several guidelines have been introduced in the science-policy interface to ensure stakeholder involvement and production of usable scientific knowledge in policy making. In this paper, we focus on coastal zone management (CZM). Over the years, dozens of CZM guidelines have been formulated, and have been extensively reviewed by, for example, Scialabba (1998), the Commission of the European Communities (CEC) (1999), Costanza (2000), and the International Council for the Exploration of the Sea (ICES) (2005). The guidelines state that policy makers, stakeholders, and scientists should start their work together by formulating policy options and research questions and close the project by jointly formulating policy and management solutions. In order for this process to succeed, it is essential that scientific results are relevant and clear to all parties involved and that there is enough time for building consensus between parties.

Implementation of these guidelines remains difficult, as the following reviews and case studies show. Folke et al. (2005) and van Kouwen et al. (2008) found that real-life cases often lack sufficient problem structuring, stakeholder involvement, and open access to relevant information. van der Have (2003) and Shipman and Stojanovic (2007) pointed out that objectives are often formulated in vague or general terms, and evaluation is sometimes left out altogether. Several authors reported that scientists do not always produce information considered relevant and useful in policy making (e.g., Sutherland et al. 2006, Lawton 2007, McNie 2007, Holmes and Clark 2008). For example, the conventional approach of formulating assumptions and deriving models to make predictions about the consequences of environmental change is often

${ }^{1}$ Deining Societal Communication, ${ }^{2}$ Faculty of Management, Radboud University, ${ }^{3}$ Department of Environmental Science, Radboud University 
unsatisfactory for complex problems, with considerable uncertainty (Sutherland 2006). Cummins et al. (2004) and Palmer et al. (2005) noted that criteria for defining and assessing economic and ecological successes are insufficiently accepted to form incentives to engage stakeholders in policy making and management. Stringer et al. (2006) and Wardekker et al. (2008) stressed that, in a participative approach, continuous communication between sectors is essential for establishing trust and commitment, even if competing interests are elicited during the process (Aarts and van Woerkum 2002). This takes time, which is not always available in the short-term-oriented political arena.

What might be the underlying cause(s) of the failure to implement CZM guidelines? Sutherland et al. (2006) organized a structured dialog between ecologists and policy makers in the UK, resulting in a list of 100 ecological questions of high policy relevance. In this discourse, two striking observations became evident. First, ecologists and policy makers each have their own rules, rationales, and rewards. Scientists seek for explanatory variables, whereas policy makers want controllable variables by which environmental issues can be handled. Second, there is a different pace to scientific progress and policy-making demands. The latter want simple, short-term solutions, whereas ecologists tend to offer advice that is complex and long term. In short, even in controversies that are ecologically and societally complex, science is expected to pacify stakeholders by providing unambiguous answers in short periods of time. We will show from an illustrative and interesting Dutch fishery policy case that this is an unrealistic expectation, and we propose an alternative approach. This so-called EVA II case dealt with mechanized shellfish fisheries of both cockles (Cerastoderma edule) and mussels (Mytilus edulis).

The EVA II case has involved many scientists and government officials for a long period, and has led to considerable public debate. It is one of the major conflicts in Dutch CZM of the past decade, where stakes were high and debates fierce (Steins 1999, Verbeeten 2000, Turnhout 2003, van Andel and Swart 2005). The case is representative for many other debates all over the world between nature conservation and fisheries, and therefore, can serve as an example. Based on a comprehensive process evaluation of this case, we analyze the role of ecological science in policy making and distil new lessons for CZM. Additionally, we develop an innovative policy strategy that includes problem structuring and dealing with societal dissent and scientific uncertainty.

\section{EVA II CASE AND ITS HISTORY}

The Dutch coastal waters are a natural resource of international importance because they provide feeding and nesting grounds to a large number of birds. In the 1970s and 1980s, the intense exploitation of shellfish (i.e., cockles and mussels) in these waters by mechanized fisheries was only of minor public and political concern. The situation changed around 1990 when low shellfish stocks coincided with high mortality of shellfish-eating birds (Steins 1999, Verbeeten 2000). A conflict arose between fishermen and conservationists because continuing mechanization of the fishing fleet during the previous decades had intensified the exploitation rate to such extent that overexploitation was feared (Ens 2003). In 1993, the Sea and Coastal Fisheries Policy came into effect, which attempted to strike a balance between the interests of the fishermen and conservationists by closing agreedupon areas to shellfish fishing. The primary goal of area closure was to restore mussel beds. In addition, a policy of food reservation for birds was implemented that allowed complete closure of the fisheries in years with low shellfish stocks. In 1998, these measures were assessed by an ecological evaluation program (EVA I). As a result, amendments were made to the policy of food reservation but these failed to settle the conflict between fishermen and conservationists. One major reason for this failure was that the government had failed to ensure that all stakeholders understood what the policy meant and what the adaptive responses would be if its objectives were not met (Imeson and van den Bergh 2006). It was also decided that a second, more thorough evaluation program (EVA II) should be carried out (Ministry of Agriculture, Nature, and Food Quality (MANFQ) 1998, Ens et al. 2002, Kamermans and Smaal 2002). In recent decades, coastal waters have also received increased protection under national legislation (since 1981) and through international treaties, including the European Union (EU) Birds Directive (since 1991) and the EU Habitats Directive (since 1996).

The EVA II program (1999-2004) was guided and monitored by a steering committee made up of 
government officials, representatives of fishing industries and nature conservation organizations, and members of the scientific management team. An EVA II policy advisory group (PAG), consisting of representatives of nature conservation and fishery organizations, was given the task of providing feedback on the new policy. The PAG reported their recommendations directly to the accountable Minister in June 2004. Right at the start of the process, a scientific audit committee of independent academics was appointed, as traditional peerreview processes would take too much time. The committee assessed the scientific quality of all the EVA II reports; its findings are in the public domain. The public summary was published in December 2003. It was discussed at four public consultation sessions and two (regional) administrative consultation sessions. The final scientific report of the EVA II program was published in August 2004. The new policy decision was published in October 2004.

In Fig. 1, a timeline is presented of the main events and phases during the EVA II research and policymaking processes. Stakeholders were explicitly invited to participate in the EVA II process. Government officials, marine ecologists, fishery biologists, fishermen, and nature conservationists were expected to work together during the complete process: from the conceptualization of research questions in 1999 to the formulation of a new policy in 2004. The Ministry expected that scientific results could bring parties together and form a bridge between vested positions; science was assumed to provide neutral, indisputable knowledge in response to experienced environmental problems (MANFQ 1999).

\section{EVA II AND THE DUTCH MARINE RESEARCH INSTITUTES}

Scientific knowledge about the effects of shellfish fisheries in the Wadden Sea has been continually debated by scientific experts, fishermen's organizations, and conservationists' organizations such as the Wadden Society and the Netherlands Society for the Protection of Birds. The main research institutes in this field are the Netherlands Institute for Sea Research (NIOZ), the Netherlands Institute for Fisheries Research (RIVO), Alterra, and the National Institute for Coastal and Marine Management (RIKZ). These institutes are specialized in ecosystems and have a history in Wadden Sea research. The NIOZ is an institute under the umbrella of the Netherlands Organization for Scientific Research. The RIVO, Alterra and RIKZ used to be linked to the Dutch government, but have been privatized and changed names. The RIVO and Alterra now form part of Imares, and RIKZ now is part of Deltares. Together, these last three institutes made up the EVA II research consortium. The NIOZ institute was, however, excluded from EVA II research. The positions taken by some NIOZ researchers during the EVA I process led some government officials to expect that NIOZ participation would generate new conflicts (Swart and van Andel 2008).

The Ministry started the EVA II program in 1999 with the installation of the steering committee (SC). The SC formulated four central policy questions the project was expected to answer: (1) what are the ecological impacts of shellfish fisheries? (2) Do the policies implemented in 1993 achieve their objectives? (3) Are the effects of shellfish fisheries within the boundaries dictated by EU directives? (4) Which counter measures should be taken if any adverse effects are identified? Policy questions were translated into agreed-upon research questions by a group of researchers, and formed the start of the research program of EVA II. The research program consisted of 22 fishery and ecological studies in the Dutch Wadden Sea and Zeeland Delta (Ens et al. 2000).

\section{EVALUATION OF THE EVA II PROCESS}

We made a post hoc evaluation of the EVA II process during 2006-2007 in collaboration with all key people involved: scientists, government officials, and stakeholder representatives. Our evaluation of the EVA II process focused on four research topics: procedures (SC, PAG, audit committee), scientific research (funding, management, audit), conservation and commercial interests (engagement stakeholders, involvement administrations), and the new policy decision (use of EVA II results, compliance with EU directives). Data were collected through 35 in-depth interviews with all key people and dossier analysis. The interviews consisted of open- and closed-format questions. The closed-format questions covered the role of scientific knowledge in policy making and beliefs on nature conservation. Dossiers included the archives of the Dutch parliament, policy documents 
Fig. 1. Timeline of the main events and phases during the EVA II research and policy- making processes.

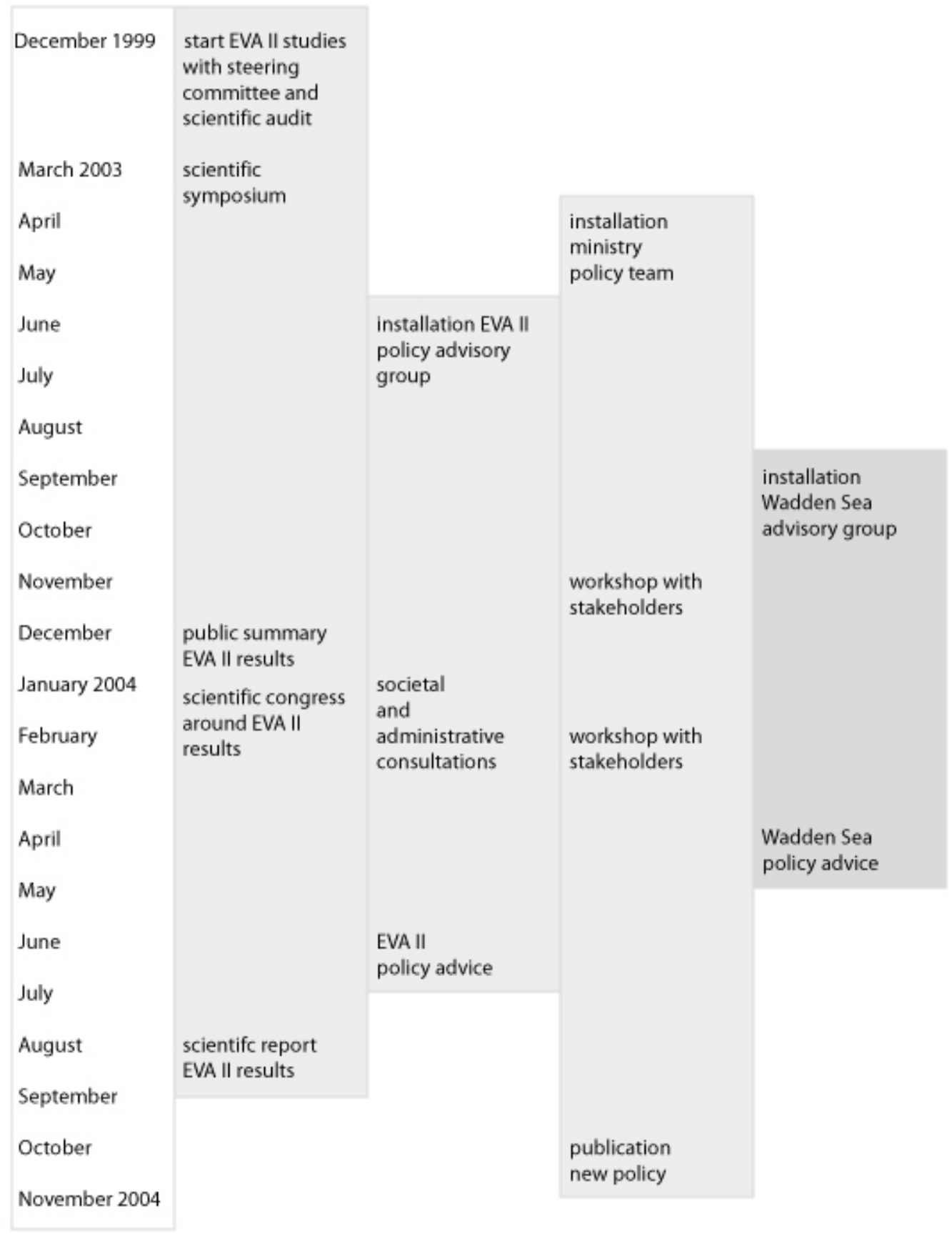


of governmental institutions involved in EVA II, articles on EVA II in three national newspapers, and the professional journals and periodicals of interest groups published from 1999 to 2004. During spring 2007, a workshop was organized with all the interviewed scientists, policy makers, and stakeholders. Our analysis of the process was presented and the additional guidelines were supported by the EVA II participants in the workshop. In addition, two separate workshops were held at the Dutch Ministry to enable policy makers to discuss the use of our improved guidelines in policy making (Hanssen et al. 2007).

In the evaluation interviews after the EVA II project, researchers and scientific audit committee members indicated they were satisfied with the research results and with the composition of the research group, which included scientists from the major Dutch governmental marine research institutesexcept the NIOZ - and all relevant (natural) scientific disciplines. Nevertheless, interviewed researchers indicated that two relevant questions were not satisfactorily answered because a larger number of experimental studies and longer timeseries data would have been needed: Is the mechanized cockle fishery making tidal flats sandier? What is the impact of mussel culture on biodiversity of the sublittoral zone and mussel stocks available to birds? (These questions are elaborated on in Ens et al. 2004).

In the interviews, SC members indicated that, although their task was clear, there was no clear procedure for communicating with their grassroots. Interviewees of the SC assess their own knowledge on methodology as not always sufficient to estimate the quality of the different scientific studies. In their view, formulating conclusions often meant taking positions already established beforehand. In addition, several scientific studies were completed behind schedule and reports published too late, in part due to inadequate or late funding. In particular, the public report in December 2003, published and edited by the MANFQ (2003), is criticized for being completed too hastily as a consensus between scientists had not yet been reached. Nevertheless, SC members felt that their goals had more or less been met.

In contrast, PAG members felt they had not, or only in part, accomplished their task. Stakeholders remained entrenched in their respective positions throughout the process. Roughly speaking, two coalitions can be distinguished: pro-fisheries and pro-nature (see also Turnhout 2003, Swart and van der Windt 2005). The pro-nature camp claims that fisheries are proven to be damaging, the profisheries camp claims the opposite. Many respondents indicated that EVA II researchers can also be placed into these two groups. The RIVO researchers are found in the pro-fisheries coalition, Alterra researchers in the pro-nature coalition. Representatives on the PAG were asked to speak in a private capacity but mostly repeated statements from their grassroots. The ongoing polarized discussion between economic and environmental stakeholders prevented the PAG from reaching consensus on shellfish fisheries, as reported in their concluding letter of advice in June 2004 to the Minister (Policy Advisory Group 2004).

In the meantime, fishermen and conservationists also defended their interests in court. Nature conservation groups, referring to the EU directives, demonstrated that they could hinder the current policy for assigning fishing permits. For them, settling matters in court became a promising alternative to the failing policy-making strategy chosen by the Ministry. Thus, nature conservation groups obtained far more power than was anticipated at the beginning of the EVA II process.

\section{EVA II AND THE POLITICAL CONTEXT}

Significant scientific parties were excluded from the EVA II process (e.g., NIOZ) and interfered from outside (Piersma et al. 2001, Camphuysen et al. 2002, Verhulst et al. 2004). Right after the publication of the public version of the EVA II results in December 2003, a scientific congress, organized by the University of Groningen, was held including these significant scientific parties as well as the EVA II participants. A conclusion reached during the congress was that the public version of the EVA II results did not sufficiently represent the overall results as there was no quality assessment and it did not refer sufficiently to international literature. Furthermore, the EVA II study was criticized because of its narrow focus (van Andel and Swart 2005, Swart and van Andel 2008).

Meanwhile the government had installed another advisory group to explore possible policies for dealing with gas exploitation, nature conservation, and shellfish fishing in the Wadden Sea area. This Wadden Sea Advisory Group published an integral 
policy plan covering the three issues in April 2004. Using the EVA II results in a wider political context, it recommended a period of 7 years for the fishing industries to develop new sustainable methods of cockle and mussel fishing. The committee also recommended allowing gas exploitation and using funds raised by this activity to mitigate environmental impacts (Meijer et al. 2004). In June 2004 , acting on an initiative by NIOZ researchers, a group of over 100 Dutch scientists wrote an open letter to the responsible Minister, expressing their concern and stressing the importance of basing decisions on scientific knowledge and insights (Anonymous 2004).

In November 2004, the Dutch House of Representatives approved the plan of the Dutch Cabinet. The plan called for closing the Wadden Sea to the mechanized cockle fishery from January 2005 on and required the mechanized mussel fishery to make its practice sustainable within 15 years without clear conditions (MANFQ 2004). Part of this political deal was to lift the moratorium on gas exploitation in the Wadden Sea and use money from gas exploitation to buy out the cockle fishing industry. The new policy decision completely abandoned the year-to-year adaptive management of shellfish fisheries, based on food requirements for shellfish-eating birds (Ens 2006). The new policy gave up food reservation as a management tool, but did not stop the food reservation discussion between fishermen and conservationists from resurfacing in the years to come. Nature conservationists were not convinced that mussel fishery could be done in a sustainable manner and took legal action against the new fishing permits. The Dutch State Council judged last year (February 2008) that these permits were illegal because of the EU Directives, based on the consideration that there is not enough scientific proof that mussel fishery does not significantly harm nature.

\section{SHORTCOMINGS OF THE EVA II PROCESS}

What, according to participants, most contributed to or hampered the EVA II process? It was generally and strongly felt that key government officials and politicians had too much room ("policy space") to interpret research conclusions in line with their preferences. This policy space was overly large because of a number of factors.
1. Scientific uncertainty was high because coastal ecosystems are complex, the number of experimental studies was limited due to restrictions in funding, and consistent timeseries data were scarce because of restrictive monitoring programs. Also, at the start of the EVA II studies, some data series were neglected because the SC did not see the relevance at that moment (later published by Philippart et al. 2007).

2. Researchers did not have enough time to reach a consensus on the interpretation of (some of the) results in the public EVA II report. This may have been amplified by the perception of strong personal opinions about the policy outcomes, which were suspected of influencing their interpretation of scientific results. Also, SC members lacked time to explain and discuss results with their grassroots. The scientific EVA II report was published almost a year later than the public report to the Minister, when the new policy was already formulated.

3. No attempt had been made to involve stakeholders and researchers in formulating policy alternatives that emerged from scientific studies. Almost none of the interviewees was satisfied with the new policy formulated by the Ministry (MANFQ 2004), which was not sufficiently based upon the EVA II results, and they agreed that a shared formulation of policy alternatives would likely have prevented this. The working plan of EVA II stated that the scientific management team would make an inventory and a scientific assessment of possible policy alternatives suggested by stakeholders in so-called scenario workshops (Ens et al. 2000). However, at the end of EVA II, most interviewees indicated that only part of the program of the proposed policy workshops had been implemented, leaving out the scientific assessment of policy alternatives.

In addition to a large policy space, the new policy was not legally robust. Environmental organizations filed a case with the European Court of Justice on this matter. According to the European Habitat Directive, a proper assessment is required for any 
activity that does not directly contribute to the conservation of the area, and activities are only allowed when it can be proven that they do not significantly harm nature. In September 2004, the European Court made it clear that such a proper assessment is also required for Dutch shellfish fisheries (case C-127/02). Law experts had been asked to judge whether the new shellfish fishery policy complied with EU directives. They concluded that the new policy was an improvement over the old one, but that many questions remained and a final judgment could only be based on the actual fishing permits (Verschuuren 2004).

Ironically, these two requirements for policy formulation, namely legal robustness and involvement of stakeholders and researchers, were both anticipated in the initial formulation of policy questions, namely (3) Are the effects of shellfish fisheries within the boundaries dictated by EU directives? and (4) Which counter measures should be taken if any adverse effects are identified? (In other words, the policy was to be formulated within the EVA II framework.) During EVA II, the Ministry decided ad hoc that these two questions in particular should be addressed in the follow-up to EVA II. In doing so, the Ministry once again positioned the scientific understanding achieved thus far and the evolving frame of reference under the full scrutiny of contesting interest groups and politicians.

\section{PROBLEM STRUCTURING IN ENVIRONMENTAL POLICY MAKING}

Problem structuring is an important step in dealing with environmental issues because it sets the scene for policy making (Klinke and Renn 2002, Pellizoni 2003). We distinguish four types of issues or problems: structured, semi-structured, semistructured complex, and unstructured complex issues. These types differ with regard to their level of scientific uncertainty and their level of societal consensus, respectively (Fig. 2) (modified after Hirschemöller et al. 2001, see also Pielke 2007). Many issues faced in environmental management can be classified as unstructured complex problems, in the sense that they are characterized by both lack of consensus on relevant beliefs and ambitions and lack of certainty with regard to relevant knowledge.

Policy makers are often too quick to use answers from ecological science to accommodate desired policies. In assuming that scientific knowledge is unassailable and decisive (Sutherland et al. 2006), they expect that a large scientific uncertainty can "easily" be diminished to small uncertainties by scientific research, and in this way, an unstructured complex issue will be transformed into a semistructured or structured issue. On the other hand, many ecologists hold the view that if policy makers are told what science reveals, correct policies will follow (Lawton 2007). In doing so, they do not account for contesting beliefs and ambitions on the issue, nor for divergent directions of solution. Stakeholders and politicians have different interests and perspectives that they try to protect and promote (Sarewitz 2004, Pielke 2007). Recently, Holmes and Clark (2008) determined that communication barriers between researchers and policy makers still persist. Scientists should avoid taking an advocacy role and instead adopt an explanatory role, and furthermore not inflate the value of their scientific results. On the other hand, policy makers have to avoid being unduly confident in the answer received from scientists and have to resist the temptation to cherry-pick the results and opinions that back up a desired policy line (Holmes and Clark 2008).

In the science-policy interface, science is not a unified and autonomous entity. Rather, competing scientific understandings are amplified by socioeconomic and political contexts (Gallopin et al. 2001, Kinzig et al. 2003). In addition to scientific facts, we need to attend to beliefs and values, tensions between institutions, different interpretations of scientific proof, and different approaches for handling uncertainties and risks (Smith and Kelly 2003, Visser 2004). In most environmental disputes, one must be aware that there is "science in context" and when the stakes are high, science easily gets politicized. Scientific claims are always interpreted from economic, legal, or political viewpoints (Guston 2001, Nowotny et al. 2001, Jasanoff 2005).

\section{ECOLOGICAL SCIENCE IN A PACIFICATION VS. A FACILITATION STRATEGY}

To be able to handle a complex, unstructured issue, the issue needs to become more structured. This can be accomplished by reducing scientific uncertainty or by reducing societal dissent. We refer to these strategies as "pacification" and "facilitation," respectively (Fig. 2). 
Fig. 2. Position of science and policy in four types of environmental issues and policy strategies to move from an unstructured to a more structured issue: pacification vs. facilitation (modified from Hisschemöller et al. 2001, see also Pielke (2007). Before reducing uncertainties by the research (horizontal arrow), consensus must be reached regarding ambitions, directions for solutions, and an interpretation framework, for example, on the accepted level of uncertainty (vertical arrow).

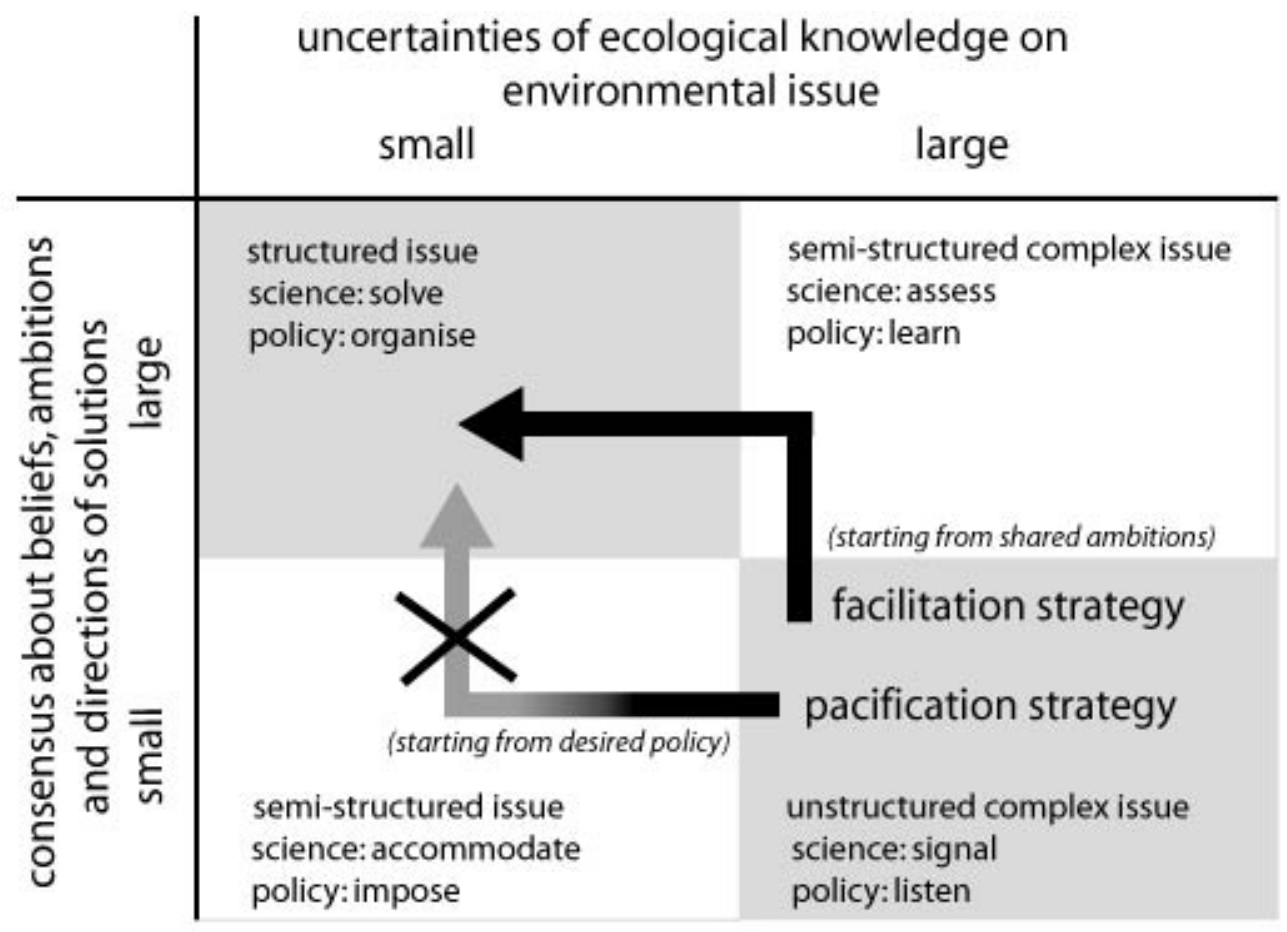

In a pacification (or depoliticizing) strategy, ecological science is used to accommodate the desired policy line (of the Ministry) by providing neutral and indisputable knowledge in response to expected problems raised by policy makers. Scientific uncertainties are assumed to be reduced by natural scientists. Scientific answers are expected to bring parties together. If there are no clear answers, government officials interpret research conclusions in line with their own preferences and in general avoid discussions with stakeholders (Sarewitz 2004, Lawton 2007, Pielke 2007). In the EVA II case, a pacification strategy was chosen by expecting that scientific results could bring parties together and bridge vested positions (MANFQ 1999).

Our study of the EVA II case shows that pacification is difficult, if not impossible, in complex unstructured issues where scientific uncertainties abound and different interests play a role (Turnhout 2003, van Andel and Swart 2005). First of all, shellfish fisheries in the Wadden Sea involve a variety of interests whereas an open dialog between conflicting points of views, including conflicting knowledge claims, has been largely absent (Hanssen et al. 2007, Swart and van Andel 2008, Turnhout et al. 2008). Secondly, sharing scientific results in order to reach consensus on their interpretation requires time, which was underestimated in EVA II. Thirdly, scientific uncertainties remain high due to the inherently complex nature of the environment. In the EV A II example, due to limited funding and commercial pressure (fisheries), only few experiments were conducted, most of the research was based on correlative studies, and only limited consistent long-term time-series data were available. Moreover, at that time, it was politically 
impossible to close areas for the purpose of experimental research (Ens et al. 2004).

To address these shortcomings of the pacification strategy in complex, unstructured issues, we introduce the so-called facilitation strategy. First, to minimize polarization in a facilitation strategy policy makers should, from the beginning, aim for shared ambitions and directions for solutions by confronting and eliciting stakeholder perspectives, despite their different value systems and competing interests (Aarts and van Woerkom 2002, Swart and van der Windt 2005), and all participants should agree on an interpretation framework for results, for example, on the accepted level of uncertainty. Before beginning the research, consensus must be reached about ambitions, directions for solutions, and an interpretation framework (Fig. 2). Taking this facilitation perspective toward policy learning, an open dialog would have served as a vehicle to discover new policy opportunities and broaden the policy scope of the Ministry (Turnhout et al. 2008).

Second, to support the creation of consensus between stakeholders including researchers, but also to ensure that knowledge is optimally used and assumptions are well founded, stakeholders' knowledge and solutions should be elicited, and confronted with the standards adhered to in a scientific framework (Leschine et al. 2003, McNie 2007). In a facilitation strategy, ecological science should not (only) contribute facts and figures to the policy arena, but should also provide educated guesses, help monitor how successful current policies are, and provide solutions to unexpected events and policy failures (Drew et al. 2004, Sutherland 2006).

Third, our study shows that ecological science should assess policy alternatives. Ecological scientists can expand and clarify the scope of options available in policy making. The involvement of ecological scientists in this stage is necessary because the uncertainties and complexity of ecological knowledge on environmental issues remain inherently high (e.g., Ascough et al. 2008); in other words, issues never become completely structured.

Policy decisions on complex, unstructured environmental issues often involve contested science. Typically there are no "facts" that unequivocally lead to a unique correct policy. The evidence that is embodied in scientific policy advice requires quality assessment. Advice should be relevant to the policy issue, scientifically tenable, and robust under societal scrutiny (Pohl 2008, van der Sluijs et al. 2008). For policy makers, using a facilitation strategy implies policy learning instead of policy imposing, by identifying, confronting, selecting, and wherever possible, integrating divergent viewpoints and knowledge. Improved communication of uncertainty leads to a deeper understanding and increased awareness of the phenomenon of uncertainty and its policy implications (Turner 2005, Sutherland et al. 2006, Wardekker et al. 2008).

In summary, the facilitation approach not only implies that ecological and economic stakeholders as users of science should participate in its agenda setting and in knowledge production, but also that ecological scientists should participate in policy formulation and evaluation, by ensuring that knowledge is optimally used and assumptions are well founded. More extensive communication between scientists and policy makers is required in order to ensure that ecologists are dealing with topics in a way that can feed into policy (McNie 2007, Pielke 2007, Holmes and Clark 2008). In the workshops we organized, participants, including the majority of the scientists and policy makers, agreed that using the facilitation strategy would have led to a more robust policy decision in the end. Successful examples from public policy-related cases illustrate the potential of this strategy (for a review see Rouwette et al. 2002).

\section{FACILITATION NEEDS ADDITIONAL GUIDELINES}

On basis of the EVA II case presented above, we expand existing guidelines for CZM. Our additions are based on the literature and this case study and are listed in italics in Fig. 3. The additions focus on structuring problems, handling scientific uncertainties, and using a facilitation strategy. All are means to increase consensus about beliefs, ambitions, and directions for solutions.

Facilitation starts with choosing an appropriate design for the policy-making process, and employing a facilitator who is neutral with regard to the content (guideline 3). Key actors should agree on procedures early on in the process and explicitly agree on the process facilitator. In doing so, all participants are enabled to jointly structure the 
Fig. 3. Guidelines for evidence-based policy making in complex environmental issues based on Scialabba (1998), the Commission of the European Communities (1999), Costanza (2000), and the International Council for the Exploration of the Sea (2005). Additions, based on our analysis, are given in bold italics.

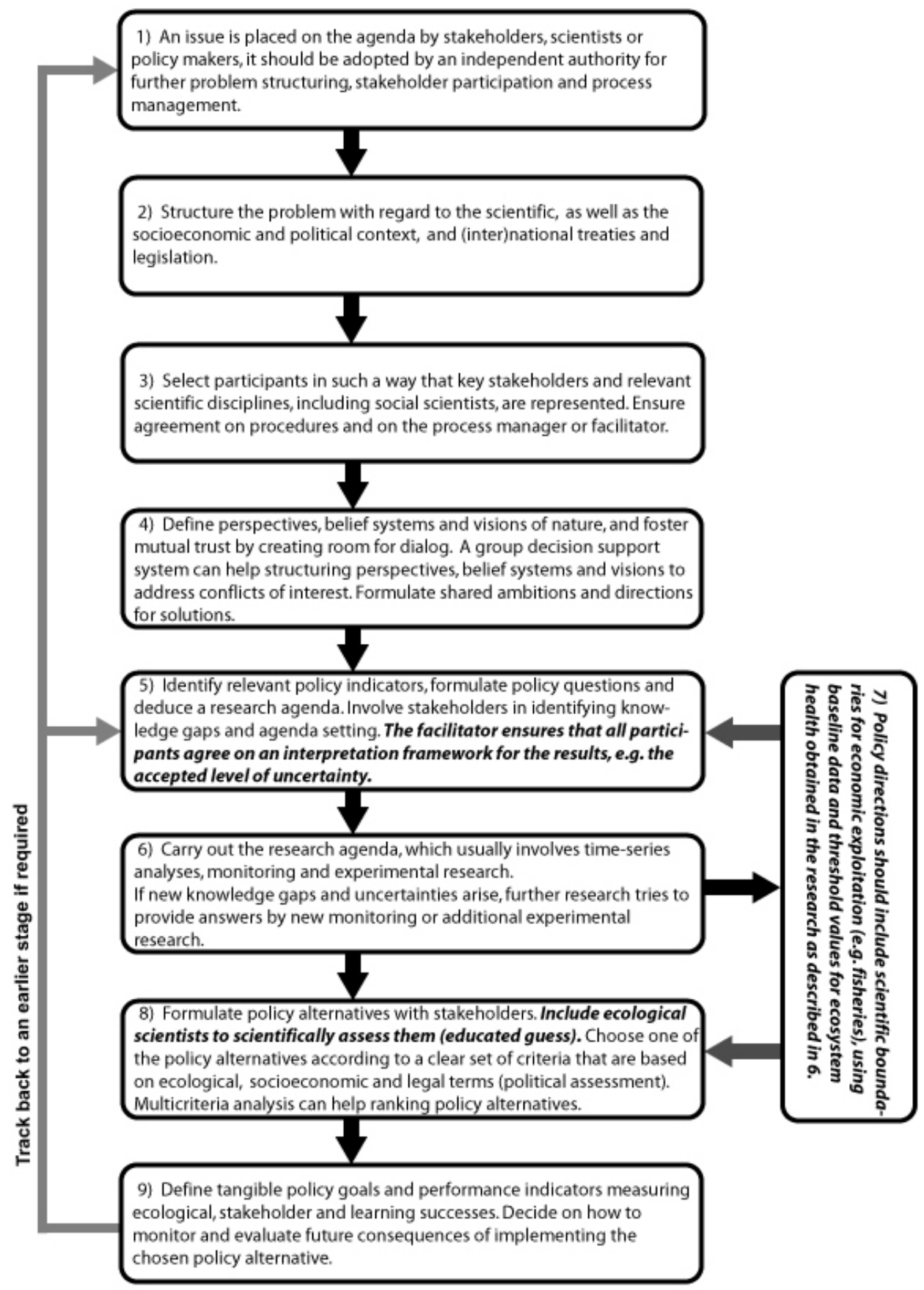


problem, identify areas of scientific uncertainty, and gather data or initiate research in order to decrease scientific uncertainty. To reduce dissent about ambitions and policy directions, articulating value and belief systems of contesting stakeholders is essential. The benefits of independent evaluation are that participants feel they are taken more seriously and may agree to outcomes sooner (Korsgaard et al. 1995, Vennix 1996, Aarts and van Woerkum 2002).

Stakeholders are involved in identifying knowledge gaps and setting the research agenda. The facilitator ensures that all participants agree on an interpretation framework for results, for example, on the accepted level of uncertainty. Differences between scientists and other participants (policy makers, stakeholders, authorities) in perceptions of uncertainty, between what is expected from science and the limits to quantification of uncertainty, should be anticipated in the deliberations (guideline $5)$.

Furthermore, policy alternatives should include scientific boundaries for economic exploitation (fisheries), using baseline data and threshold values for ecosystem health (guideline 7). In this way, apart from achieving a sound policy, (EU) regulations will be met. It may also diminish the impact of the precautionary principle: it is no longer enough to establish that "no impact cannot be proven." It now has to be proven that fishery impacts remain under threshold values. Baseline data and threshold values for ecosystem health must be anticipated in the policy and research questions (as part of guideline 5), and can be derived from historical and monitoring data, and additional experimental research (formulated in guideline 6). For each proposed policy alternative, a sound scientific assessment by a team of ecological experts in all relevant fields should be made (guideline 8). Ecological scientists can expand and clarify the scope of options available in policy making, in using policy workshops, by extrapolation of ecological models, and by expert judgments (educated guesses). A scientific assessment should thus provide, apart from the usual relevant scientific information for underpinning policy choices (formulated in guideline 6), an indication of the ecological consequences of the proposed policy alternatives.

Note that in a facilitation strategy, scientists have to be prepared for "making educated guesses" or "assessing policy alternatives," while at the same time precautions should be taken that scientists are not tempted or urged to make guesses on topics outside their expertise. Note furthermore that in the facilitation strategy, as in the pacification strategy, uncertainty should be reduced by scientific research, providing facts and figures. The proposed educated guesses can complement, but never replace, research efforts.

By applying guidelines 5 to 8 , a more significant role for ecological science in policy making can be realised. Our supplements to the existing guidelines may function as significant tools for organizing future policy processes on complex ecological controversies. The additional guidelines were supported by the EVA II participants in workshops held as part of our research (Hanssen et al. 2007). Several methods to facilitate the process are available from the social sciences. For instance, group decision support systems (van Kouwen et al. 2008), multicriteria analyses (Portman 2007), game-theory models (Sutherland 2006), adaptive governance tools (Folke et al. 2005), or advocacy coalition frameworks (Leschine et al. 2003) are proven instruments in CZM.

\section{EVA II AND THE GUIDELINES}

Below, we will interpret the EVA II process in terms of the guidelines (Fig. 3). Guidelines 1 and 2 were more or less followed (MANFQ 1999). Guideline 3 was partly followed. Social scientists were not included. In the EVA II case, the appointment of a neutral process facilitator was intended. This was not achieved, according to many respondents (Hanssen et al. 2007). It would have alleviated one of the main shortcomings of EVA II, namely the perceived strong personal opinions about the policy outcomes, which were suspected to have influenced the interpretation of scientific results (see the section "Shortcomings in the EVA II process" above). In general, it should be realised that deliberation takes time (e.g., McNie 2007), which particularly held for guidelines 3-7. In the EVA II process, no deliberation time was planned for according to the respondents (see "Shortcomings in the EVA II process" above).

Guideline 4 was not followed. Guideline 5 was followed (Ens et al. 2000), except that an interpretation framework for results was lacking. Guideline 6 was partially met: research results 
answered the policy questions, albeit interviewed researchers indicated that two relevant research questions were not satisfactorily answered because a larger number of experimental studies and longer time-series data would have been needed (Ens et al. 2004). Also, due to restrictive funding and scarcity of consistent time series in the EVA II research, uncertainties remained high (see "Shortcomings in the EVA II process" above).

With regard to guideline 7, initially, two extra policy questions were formulated: (3) Are the effects of shellfish fisheries within the boundaries dictated by EU directives? and (4) Which counter measures should be taken if any adverse effects are identified? During EVA II, the Ministry decided ad hoc that these two questions in particular should be addressed in the follow-up to EVA II. Therefore, the assessment of threshold values for ecosystem health was no longer part of the research program. Regarding guideline 8, the working plan of EVA II stated that the scientific management team would make an inventory and a scientific assessment of possible policy alternatives suggested by stakeholders in so-called scenario workshops (Ens et al. 2000). However, at the end of EVA II, most interviewees indicated that only part of the program of the proposed policy workshops had been implemented, leaving out the scientific assessment of policy alternatives. The Ministry probably no longer felt the urgency to organize the workshops when the policy questions mentioned above were abandoned. With regard to guideline 9, this topic was not included in our evaluation of the EVA II case.

\section{CONCLUSIONS}

Ecologists can and do influence government policy on the environment, but often through complex interactions that can be painfully slow. Politicians and policy makers can easily use uncertainties in ecological knowledge as an argument to postpone decisions (Lawton 2007). Sometimes science even plays an advocacy role in controversial policy making (Turnhout et al. 2008). In this paper, we provided guidelines to redirect and settle environmental discourses by ecological fact finding instead of opportunistic politics and policy making.

To be able to handle an unstructured complex issue, the issue needs to become more structured. This can be accomplished in two ways (Fig. 2). We showed that the use of a pacification strategy, in which science is expected to pacify stakeholders, is not an answer, as uncertainties are likely to remain high due to different pacing of scientific progress and policy-making demands. Instead, we propose a facilitation strategy in which stakeholders elaborate shared ambitions and directions for solutions, and ecological scientists extend their participation in scientifically assessing policy alternatives. In the EVA II case, the pacification strategy was employed, and ecological science was used to accommodate the desired policy of authorities. At the same time, in choosing a pacification strategy, policy makers narrow the policy scope. However, with limited funding and within a limited timeframe, no significant reduction of scientific uncertainty can be expected in a complex environmental issue. Simultaneously, without a shared ambition and shared policy formulation, the results of scientific research remain open to multiple interpretations and contested. In the EVA II case, the dispute was ultimately taken to court.

We recommend an alternative strategy based on facilitation. An improved set of guidelines for this strategy is presented in Fig. 3. It boils down to structuring the issue by reducing societal dissent. Despite different value systems and competing interests, participants aim at shared ambitions and directions for solutions by confronting and eliciting each others' perspectives. Facilitation is a two-way process, engaging government officials, stakeholders, and scientists in a joint appraisal process, providing for mutual interrogation and consistency of framing, eliciting and documenting consensual judgements as well as divergent views. Ecological scientists, apart from providing facts and figures, should assess the policy alternatives within a scientific framework. This will also allow policy makers and stakeholder representatives to deal with uncertainty. Obviously, both should abandon the unrealistic expectation that science can settle the dispute. Our guidelines offer a tool to balance economic and ecological interests and shared policy formulation by scientific inquiry instead of political opportunity. By referring to these guidelines, ecologists can maintain their independence and authority if they engage in policy making. If these guidelines were adhered to, policy makers and politicians could for instance not ignore the fact that a proper policy of food reservation for shellfish-eating birds should be continued and even tightened up in the new policy decision. 
Of course we realise that finding a balance between scientific inquiry and professional know-how, between a technocratic and a deliberative approach, is an ongoing endeavor for authorities and all parties involved. Nevertheless, scientists often know the areas where conflict is likely in the future; they should prepare themselves at an early stage so that they better understand the ecology of these systems before the conflict becomes entrenched. This requires policy makers to allocate funds to these areas at an early stage if the conflict escalation is to be minimized. In current literature, we observe a tendency to minimize the role of natural science and emphasize the role of policy making and management. "More natural science may not make much difference" tends to become the new policy adage (Hilborn 2007, Bundy et al. 2008). To oppose this, ecologists and environmental scientists have to bring forward the essential role of ecological science in understanding ecosystem complexity in policy forums. Moreover, they have to claim a role in the scientific assessment of policy options when asked to provide scientific information to policy makers.

Only when authorities, policy makers, stakeholders, and of course politicians, explicitly recognize the requirements and limitations of scientific research, can ecological science become more relevant to policy making in these complex environmental controversies. Otherwise, scientific uncertainties may easily induce science to become a plaything in the hands of vested interests, instead of providing the best available knowledge and assessing different policy alternatives. In our case, practice has shown that this ends in court.

Responses to this article can be read online at: http://www.ecologyandsociety.org/voll4/iss l/art43/ responses/

\section{Acknowledgments:}

We thank our respondents for their involvement and for the generosity with which they shared their experiences with us, in terms of both time and frankness. The Department of Knowledge of the Ministry of Agriculture, Nature, and Food Quality financially supported the research; we thank Chantal van Dam, Wim Wiersinga, Sytze Braaksma, Maarten Bruns, and Wilbert Schermer Voest of the Ministry for their commitment to the project and skillful supervision. We thank Prof. Dr. Peter Herman (Department of Spatial Ecology of the Netherlands Institute of Ecology), Dr. Rob Leuven (Department of Environmental Science of the Radboud University Nijmegen) and Wim Wiersinga (Department of Knowledge of the Ministry of Agriculture, Nature, and Food Quality) and the four anonymous reviewers of our manuscript for their critical reading and valuable comments.

\section{LITERATURE CITED}

Aarts, N., and C. van Woerkom. 2002. Dealing with uncertainty in solving complex problems. Pages 421-436 in C. Leeuwis and R. Pyburn, editors. Wheelbarrows full of frogs. Social learning in rural resource management. Koninklijke van Gorkum, Assen, The Netherlands.

Anonymous. 2004. Brandbrief over schade kokkelvisserij. [Urgent letter concerning the damage caused by cockle fishery.] Trouw, 11 june.

Ascough, J. C. II, H. R. Maier, J. K. Ravalico, and M. W. Strudley. 2008. Future research challenges for incorporation of uncertainty in environmental and ecological decision-making. Ecological Modelling 219:383-399.

Bundy, A., R. Chuenpagdee, S. Jentoft, and R. Mahon. 2008. If science is not the answer, what is? An alternative governance model for the world's fisheries. Frontiers in Ecology 6:152-155.

Camphuysen, C. J., C. M. Berrevoets, H. J. W. M. Cremers, A. Dekinga, R. Dekker, B. J. Ens, T. M. van der Have, R. K. H. Kats, T. Kuiken, M. F. Leopold, J. van der Meer, and T. Piersma. 2002. Mass mortality of common eiders (Somateria mollissima) in the Dutch Wadden Sea, winter 1999/2000: starvation in a commercially exploited wetland of international importance. Biological Conservation 106:303-317.

Commission of the European Communities (CEC). 1999. Towards a European Integrated Coastal Zone Management ICZM strategy. General Principles and Policy Options. CEC, Luxembourg.

Costanza, R. 2000. The ecological, economic, and social importance of oceans. Pages 393-403 in C. Sheppard, editor. Seas at the millennium: an 
environmental evaluation. Elsevier Science, Amsterdam, The Netherlands.

Cummins, V., C. O Mahony, and N. Connolly. 2004. Review of integrated coastal zone management and principles of best practice Prepared for the Heritage Council. Coastal and Marine Resources Centre, Cork, Ireland.

Drew, C. H., T. L. Nyerges, and M. L. Leschine. 2004. Promoting transparency of long-term environmental decisions: the Handford decision mapping system pilot project. Risk Analysis 24:1641-1664.

Ens, B. J. 2003. What we know and what we should know about mollusc fisheries and aquacultures in the Wadden Sea. Pages 121-145 in W. J. Wolff, K. Essink, A. Kellerman, and M. A. van Leeuwen, editors. Challenges to the Wadden Sea area. The Tenth International Scientific Wadden Sea Symposium, University of Groningen, Groningen, The Netherlands.

Ens, B. J. 2006. The conflict between shellfisheries and migratory waterbirds in the Dutch Wadden Sea. Pages 806-811 in G. C. Boere, C. A. Galbraith, and D. A. Stroud, editors. Waterbirds around the world. The Stationary Office, Edinburgh, UK.

Ens, B. J., R. Lanters, and A. C. Smaal. 2000. Onderzoeksplan EVA II. [Research plan EVA II.] Alterra / RIKZ / RIVO, Den Burg / The Hague / Yerseke, The Netherlands.

Ens, B. J., R. Lanters, and A. C. Smaal. 2002. EVA II: evaluating the Dutch policy of shellfish fishing in 2003. Wadden Sea Newsletter 2:22-24.

Ens, B. J., A. Smaal, and J. De Vlas. 2004. The effects of shellfish fishery on the ecosystems of the Dutch Wadden Sea and Oosterschelde. Alterra Report 1011 (RIVO report C056/04. RIKZ/2004.031) Alterra, Wageningen, The Netherlands. [online] URL: www2.alterra.wur.n1/Webdocs/PDFFiles/ Alterrarapporten/AlterraRapport1011.pdf.

Folke, C., T. Hahn, P. Olsson, and J. Norberg. 2005. Adaptive governance of social-ecological systems. Annual Review of Environment and Resources 30:441-473.

Gallopin, G. C., S. Funtowicz, M. O'Connor, and J. R. Ravetz. 2001. Science for the twenty-first century: from social contract to the scientific core. International Social Science Journal 168:219-229.

Guston, D. H. 2001. Boundary organisations in environmental policy and science: an introduction. Science, Technology and Human Values 26:399408.

Hanssen, L. S. A. M., M. M. van Katwijk, A. Glasmeier, and E. A. J. A. Rouwette. 2007. Als de feiten spreken. Een evaluatie van het EVA II proces. [When the facts speak. An evaluation of the EVA II process.] Deining Consultancy, Nijmegen, The Netherlands.

Hilborn, R. 2007. Reinterpreting the state of fisheries and their management. Ecosystems 10:1362-1369.

Hisschemöller, M., R. Hoppe, P. Groenewegen, and C. Midden. 2001. Knowledge use and political choice in Dutch environmental policy: a problemstructuring perspective on real life experiments in extended peer review. Pages 437-470 in $\mathrm{M}$. Hisschemöller, R. Hoppe, W. N. Dunn, and J. R. Ravetz, editors. Knowledge, power and participation in environmental policy analysis and risk assessments. Transaction Publishers, New Brunswick, New Jersey, USA and London, UK.

Holmes, J., and R. Clark. 2008. Enhancing the use of science in environmental policy-making and regulation. Environmental Science and Policy 11:702-711.

Imeson, R. J., and J. C. J. M. van den Bergh. 2006. Policy failure and stakeholder dissatisfaction in complex ecosystem management: the case of the Dutch Wadden Sea shellfishery. Ecological Economics 56:488-507.

International Council for the Exploration of the Sea (ICES). 2005. Report of the working group on integrated coastal zone management, by correspondence (ICES CM 2005/E:09). ICES, Copenhagen, Denmark.

Jasanoff, S. 2005. Designs on nature. Science and democracy in Europe and the United States. Princeton University Press, Princeton, New Jersey, USA and Oxford, UK.

Kamermans, P., and A. C. Smaal. 2002. Mussel culture and cockle fisheries in the Netherlands: 
finding a balance between economy and ecology. Journal of Shellfish Research 21:509-517.

Kinzig, A., D. Starret, A. Kenneth, S. Aniyar, B. Bolin, P. Dasgupta, P. Ehrlich, C. Folke, M. Hanemann, G. Heal, M. Hoel, A. Jansson, B. Jansson, N. Kautsky, S. Levin, J. Lubchenko, K. Mäler, S. W. Pacala, S. H. Schneider, D. Siniscaldo, and B. Walker. 2003. Coping with uncertainty: a call for a new science-policy forum. Ambio 32:330-335.

Klinke, A., and O. Renn. 2002. A new approach to risk evaluation and management: risk-based, precaution-based, and discourse-based strategies. Risk Analysis 22:1071-1094.

Korsgaard, M., D. Schweiger, and H. Sapienza. 1995. Building commitment, attachment, and trust in strategic decision making teams. The role of procedural justice. Academy of Management Journal 38:60-84.

Lawton, J. H. 2007. Ecology, politics and policy. Journal of Applied Ecology 44:461-474.

Leschine, T. M., B. E. Ferriss, K. P. Bell, K. K. Bartz, S. MacWilliams, M. Pico, and A. K. Bennett. 2003. Challenges and strategies for better use of scientific information in the management of coastal estuaries. Estuaries 26:1189-1204.

McNie, E. C. 2007. Reconciling the supply of scientific information with user demands: an analysis of the problem and review of the literature. Environmental Science and Policy 10:17-38.

Meijer, W., P. C. Lodders-Elfferich, and L. M. L. H. A. Hermans. 2004. Ruimte voor de Wadden. [Space for the Wadden.] Ministry of Housing, Spatial Planning and the Environment (VROM), The Hague, The Netherlands.

Ministry of Agriculture, Nature, and Food Quality (MANFQ). 1998. Structuurnota Zee- en Kustvisserij: Evaluatie van de Maatregelen in de Kustvisserij gedurende de Eerste Fase (1993-97). (Structure report on sea and coastal fishing: Evaluation of Measures in the Coastal Fishery Branch during the First Phase (1993-97).) MANFQ, The Hague, The Netherlands.

1999. Schelpdiervisserij in de kustwateren 1999-2003. Projectplan voor het evaluatieprogramma tweede fase (EVA II). (Shellfish fisheries in coastal waters 1999-2003. Project plan for the evaluation program second phase (EVAII).) MANFQ, The Hague, The Netherlands.

—. 2003. Resultaten wetenschappelijk onderzoek EVA-II. Publieksversie. (Results of the scientific research by EVA II. Public version.) MANFQ, The Hague, The Netherlands.

2004. Ruimte voor een zilte oogst. Naar een omslag in de Nederlandse schelpdiercultuur. Beleidsbesluit Schelpdiervisserij 2005-2020. (Scope for a briny harvest. Toward a shift in Dutch shellfish culture. Policy Decision on Shellfish Fishery 20052020.) MANFQ, The Hague, The Netherlands.

Nowotny, H., P. Scott, and M. Gibbons. 2001. Rethinking science: knowledge and the public in an age of uncertainty. Polity Press, Cambridge, UK.

Palmer, M. A., E. S. Bernhardt, J. D. Allan, P. S. Lake, G. Alexansder, S. Brooks, J. Carr, S. Clayton, C. N. Dahm, J. Follstad Shah, D. L. Galat, S. G. Loss, P. Goodwin, D. D. Hart, B. Hassett, R. Jenkinson, G. M. Kondolf, R. Lave, J. L. Meyer, T. K. O'Donnell, L. Pagano, and E. Sudduth. 2005. Standards for ecologically sucessful river restoration. Journal of Applied Ecology 42:208-217.

Pellizoni, L. 2003. Knowledge, uncertainty and the transformation of the public sphere. European Journal of Social Theory 6:327-355.

Philippart, C. J. M., J. J. Beukema, G. C. Cadée, R. Dekker, P. W. Goedhart, J. M. van Iperen, M. F. Leopold, and P. M. J. Herman. 2007. Impacts of nutrient reduction on coastal communities. Ecosystems 10:95-118.

Pielke, R.A. 2007. The honest broker. Making sense of science in policy and politics. Cambridge University Press, Cambridge, UK.

Piersma, T., A. Koolhaas, A. Dekinga, J. J. Beukema, R. Dekker, and K. Essink. 2001. Longterm indirect effects of mechanical cockle-dredging on intertidal bivalve stocks in the Wadden Sea. Journal of Applied Ecology 38:976-990.

Pohl, C. 2008. From science to policy through transdisciplinary research. Environmental Science and Policy 11:46-53. 
Policy Advisory Group. 2004. Duurzaam en dynamisch. Advies van de Beleidsadviesgroep EVA II inzake het toekomstig beleid voor de schelpdiervisserij. [Sustainable and dynamic. Advice of the Policy Advisory Group EVA II concerning the future policy for shellfish fisheries.] LNV, The Hague, The Netherlands.

Portman, M. E. 2007. Zoning design for crossborder marine protected areas: the Red Sea Marine Peace Park case study. Ocean and Coastal Management 50:499-522.

Rouwette E., J. Vennix, and T. van Mullekom. 2002. Group model building effectiveness: a review of assessment studies. System Dynamics Review 18:5-45.

Sarewitz, D. 2004. How science makes environmental controversies worse. Environmental Science and Policy 7:385-403.

Scialabba, N., editor. 1998. Integrated coastal area management and agriculture, forestry and fisheries. Food and Agriculture Organization (FAO) guidelines. Environmental and Natural Resources Services, FAO, Rome, Italy.

Shipman, B., and T. Stojanovic. 2007. Facts, fictions, and failures of integrated coastal zone management in Europe. Coastal Management 35:375-398.

Smith, W., and S. Kelly. 2003. Science, technical expertise and the human environment. Progress in Planning 69:321-394.

Steins, N.A. 1999. All hands on deck. An interactive perspective on complex common-pool resource management based on case studies in the coastal waters of the Isle of Wight (UK), Connemara (Ireland) and the Dutch Wadden Sea. Dissertation, Wageningen University and Research Centre, Wageningen, The Netherlands.

Stringer, L. C., A. J. Dougill, E. Fraser, K. Hubacek, C. Prell, and M. S. Reed. 2006. Unpacking "participation" in the adaptive management of social-ecological systems: a critical review. Ecology and Society 11(2): 39. [online] URL: http://www.ecologyandsociety.org/vol11/iss2/ $\operatorname{art39/.}$
Sutherland, W. J. 2006. Predicting the ecological consequences of environmental change: a review of the methods. Journal of Applied Ecology 43:599616.

Sutherland, W. J., S. Armstrong-Brown, P. R. Armsworth, T. Brereton, J. Brickland, C. D. Campbell, D. E. Chamberlain, A. I. Cooke, N. K. Dulvy, N. R. Dusic, M. Fitton, R. P. Freckleton, H. C. J. Godfray, N. Grout, H. J. Harvey, C. Hedley, J. J. Hopkins, N. B. Kift, J. Kirby, W. E. Kunin, D. W. MacDonald, B. Marker, M. Naura, A. R. Neale, T. Oliver, D. Osborn, A. S. Pullin, M. E. A. Shardlow, D. A. Showler, P. L. Smith, R. J. Smithers, J.-L. Solandt, J. Spencer, C. J. Spray, C. D. Thomas, J. Thompson, S. E. Webb, D. W. Yalden, and A. R. Watkinson. 2006. The identification of 100 ecological questions of high policy relevance in the UK. Journal of Applied Ecology 43:617-627.

Swart, J.A. A., and J. van Andel. 2008. Rethinking the interface between ecology and society. The case of the cockle controversy in the Dutch Wadden Sea. Journal of Applied Ecology 45:82-90.

Swart, J. A. A., and H. J. van der Windt. 2005. Visions of nature and environmental sustainability: shellfish fishing in the Dutch Wadden Sea. Restoration Ecology 13:183-192.

Turner, R. E. 2005. On the cusp of restoration: science and society. Restoration Ecology 13:165173.

Turnhout, E. 2003. Ecological indicators in Dutch nature conservation. Dissertation, Aksant, Amsterdam, The Netherlands.

Turnhout, E., M. Hisschemöller, and H. Eijsackers. 2008. Science in Wadden Sea policy: from accommodation to advocacy. Environmental Science and Policy 11:227-239.

van Andel, J., and J. A. A. Swart. 2005 At the interface between science and politics: the case of cockle fishery in the Wadden Sea. Pages 73-77 in J. H. Koeman and J. D. Schiereck, editors. Responsibilities of environmental research. Royal Netherlands Academy of Arts and Science (KNAW), Amsterdam, The Netherlands.

van der Have, T. M. 2003. Birds and shellfisheries in the Dutch Wadden Sea: a case of adaptive 
resource management? Pages 147-172 in W. J. Wolff, K. Essink, A. Kellerman, and M. A. van Leeuwen, editors. Challenges to the Wadden Sea area. The Tenth International Scientific Wadden Sea Symposium, University of Groningen, Groningen, The Netherlands.

van der Sluijs, J. P., A. C. Petersen, P. H. J. Janssen, J. S. Risbey, and J. R. Ravetz. 2008. Exploring the quality of evidence for complex and contested policy decisions. Environmental Research Letters 3: 024008.

van Kouwen, F. A., C. Dieperink, P. P. Schot, and M. J. Wassen. 2008. Applicability of decision support systems for integrated coastal zone management. Coastal Management 36:19-34.

Vennix. J. 1996. Group model building: facilitating team learning using system dynamics. Wiley, Chichester, UK.

Verbeeten, T. 2000. Wise use of the Wadden Sea? A study of policy-oriented learning. Wadden Sea Newsletter 2:7-9.

Verhulst, S., K. Oosterbeek, A. L. Rutten, and B. J. Ens. 2004. Shellfish fishery severely reduces condition and survival of oystercatchers despite creation of large marine protected areas. Ecology and Society 9(1): 17. [online] URL: http://www.eco logyandsociety.org/vol9/iss1/art17/.

Verschuuren, J. M. 2004. Juridische risicoanalyse 'Beleidsbesluit Schelpdiervisserij 2005-2020' met het oog op toetsing aan de Vogel- en Habitatrichtlijn. [Legal risk analysis "Policy decision on shellfish fishery 2005-2020" with an eye to the Bird and Habitat Directives.] Report, Centre for Legislative Studies,University of Tilburg, Tilburg, The Netherlands.

Visser, L. E., editor. 2004. Challenging coasts. Transdisciplinary excursions into integrated coastal zone development. Amsterdam University Press, Amsterdam, The Netherlands.

Wardekker, J. A., J. P. van der Sluijs, P. H. M. Janssen, P. Kloprogge, and A. C. Petersen. 2008. Uncertainty communication in environmental assessments: views from the Dutch science-policy interface. Environmental Science and Policy 11:627-641. 